\title{
Great Initiatives for a Great Cause: Policy Making In United Kingdom to Limit Smoking
}

\author{
Ramsha Khan ${ }^{1}$ and Muhammad Salman Haider Qureshi ${ }^{2^{*}}$ \\ ${ }^{1}$ Department of Health Promotion and Public Health, University of West London, United Kingdom \\ ${ }^{2}$ Department of Public Health, Khyber Medical University, Pakistan
}

"Corresponding author: Muhammad Salman Haider Qureshi, Institute of Public Health and Social Sciences, Khyber Medical University, Peshawar, Pakistan, Tel: +03339175608; E-mail: pmc.salmanqureshi@gmail.com

Received date: January 23, 2018; Accepted date: January 29, 2018; Published date: February 05, 2018

Copyright: (c) 2018 Khan R, et al. This is an open-access article distributed under the terms of the Creative Commons Attribution License, which permits unrestricted use, distribution, and reproduction in any medium, provided the original author and source are credited.

\section{Commentary}

Smoking affects the lives of many people. Even though the prevalence of smoking is continuously reducing, there are still about 1 in 5 people who do smoking [1]. Smoking does not only affect the smokers but also the people who are breathing in that smoke. Passive smoking which is also known as second hand smoking affect many non-smokers by increasing their chance of developing many health issues such as lung cancer, larynx and pharynx cancers. In UK, thousands of people die each year due to the diseases caused by passive smoking. These diseases include stroke, heart diseases and lung disease [2].

A policy can be defined as; "A broad statement of the principles of how to proceed in relation to a specific issue, such as a national policy on transport, a local authority policy on housing or a policy on how to deal with alcohol issues in a workplace" [3]. Power is "The ability to influence people, and in particular to control resources" [4]. Moreover, Public health is "the science and art of promoting and protection health and well-being, preventing ill-health and prolonging life through the organised efforts of society" [5].

In United Kingdom alone, nearly 114,000 smokers die per year because of the illnesses caused by smoking. Smoking can become the very common avoidable cause for developing many health issues for example, lung cancer, chronic heart diseases, bladder cancer and many more [6]. Despite the fact that the smoking prevalence has been continuously decreased, but still every year smoking is the cause of approximately a hundred thousand deaths from which some eleven thousand deaths have been occurred due to passive smoking. Furthermore, smoking has become the reason behind the increase of health inequalities. Hence, between the south and the north, it remained the cause of increasing difference in life expectancy. In order to control smoking in public places, the first white paper was published by Labor government in 1998 related to tobacco. In 2005, the policy on partial ban on smoking in public places was proposed by Labor party. At present, the complete ban has been broadly accepted [7].

When considering political ideology, Labour government which is left wing that means their belief is equality between people and their future goal is to increase the tax of rich people in order to support poor people. Whereas on the other hand Conservative government which is right wing, believe in equity which means they believe in not paying for other people support for example in terms of health services and education. Ideology is defined as "A set of ideas or beliefs which underlies and justifies the actions of governments, corporations or religious groups, or attempts to undermine these entities" [8].
The policy regarding ban on smoking in public places, was first introduced by labour government. In 2004, the aim of the ban on smoking in public places which was proposed by Labour government, was to provide supportive environment for not only protecting the public from the bad effects of second hand smoking but also to encourage the smokers to quit smoking [9].

Implementing the ban on smoking in public places has helped a lot in developing healthy environment by decreasing the risk of many health issues caused due to passive smoking. In United Kingdom, the main reason behind the premature death is smoking. Banning smoking in public places will be very beneficial for the non-smokers in public and work places as it will reduce their risk of breathing in a smoking environment which will then decrease their risk of developing many health issues such as lung cancer, heart diseases, childhood respiratory disease, asthma attacks and many more. The Government is currently taking in view the Health Bill, which is focusing on the inclusion of smoke free environment by making sure that the public and work places should become completely smoke free. The Government aim behind this policy is to enable the non-smokers to live in an environment which is smoke free. It will also encourage the smokers to quit smoking more easily in workplaces and public places as the pressure to smoke in social environment will also be decreased. This policy will also help to decrease the cost by reducing the health issues cause by smoking. It will play an important role in terms of safety that reducing the risk of fire [10].

Although the government and public showed a lot of support towards banning smoking in public places, there is still some criticism of the ban. Organizations, who are involved in raising their voice on behalf of smokers and tobacco trade, claimed that the environment can be protected from smoke by using ventilators. In response to this claim the medical professionals said that the environment cannot be protected by ventilators from developing the risk of lung cancer [11]. Some criticism also involves raising the point that banning smoking in public places affects the individual's liberty and freedom as it takes away their right to decide for themselves whether they want to smoke or not. Opponents also say that by banning smoking in public places, the government revenues will also be affected as the taxes paid by the people who smoke and tobacco industries will be reduced resulting in low income [12].

The public highly supported the ban as in $2006,90 \%$ supported the smoking limitations in restaurants. In general, $53 \%$ of the population was highly agreed and $24 \%$ just agreed. The ban was also supported by Liberal Democrats. A free vote from Conservative government had been given to the Tory MPs on the bill [7]. Public Health England also supports the ban as their future objective is to see smoke free public by 2025 [10]. It is stated in the policy of the 2010 to 2015 Liberal 
Citation: Khan R, Qureshi MSH (2018) Great Initiatives for a Great Cause: Policy Making In United Kingdom to Limit Smoking. J Health Educ

Page 2 of 2

Democrat and Conservative coalition government that the anti-smoke campaigns will be working in order to motivate people to quit smoking by educating them the harmful effects caused by smoking. They will also advocate people to avoid smoking in cars and homes as it badly affects the health of the children [13].

People who want to quit smoking can get a brilliant help from National Health Service (NHS) such as Local NHS stop smoking services, NHS smoking helpline and many more. Employers can also get help regarding the support they can give their workers from their local NHS stop smoking services. Another free programmer proposed by NHS is Together, which motivates smokers to quit smoking by educating them through medical study. Gosmokefree.co.uk is another online support which can help the smokers to stop smoking by giving them a proper guidance. The workforce will involve the Public health professionals, doctors, nurses, social workers and other relevant staff [14].

At the end, when considering the health of the public, it is proved that smoking is the main cause of many diseases such as respiratory diseases, heart diseases, some cancers including lung cancer and many other health issues. Secondly, as discussed earlier that passive or second hand smoking has also become the reason behind many health risks, hence it is very important to provide healthy environment to people in which they breathe in. For this purpose, the policy on the ban on smoking in public places plays an important role. Evidence has also shown that the ban has been widely accepted not only by the government but also by the public. However, some critics are also present, which argue that the ban has taken away the right of people to decide independently for themselves and to make their own choices. However, while considering a broader perspective, in our view point, the implementation of the ban will be beneficial as it will decrease the cost for treating sick people due to smoking.

\section{References}

1. Public Health England (2015) Health matters: smoking and quitting in England. (Accessed: 10 July 2017).

2. Cancer research UK (2016) Passive smoking. (Accessed: 10 July 2017).

3. Scriven A (2010) Promoting Health a practical guide, Edinburgh, Elsevier, pp: 1-67.

4. Buse K, Mays N, Walt G (2012) Making health policy. 2nd edn Maidenhead: McGraw-Hill/Open University Press, pp: 1-28.

5. The UK's Faculty of Public Health (2010) What is public health. Available at: http://www.fph.org.uk/what_is_public_health (Accessed: 11 July 2017).

6. Firth L (2010) Smoking and health. Cambridge: Independence.

7. The institute of Government (2007) The ban on smoking in public places. (Accessed: 12th July 2017).

8. Naidoo J, Wills J (2016) Foundations for health promotion. 4th edn, Elsevier, London, pp: 1-67.

9. Evans D, Coutsaftiki D, Fathers CP (2017) Health Promotion and Public Health for Nursing Students. 3rd edn, London: Sage publications, pp: 1-63.

10. Gov.UK (2006) Government response to the House of Commons Health Committee's first report of session 2005 to 2006: smoking in public places. (Accessed 13th July 2017).

11. Politics.co.uk (2017) Smoking ban. (Accessed 13th July 2017).

12. Connectusfund.org (2015) 14 Central Pros and Cons of Smoking Bans. (Accessed: 13th July 2017)

13. Gov UK (2015) Policy paper 2010 to 2015 government policy: smoking. (Accessed: 15th July 2017).

14. Smokefreeengland.co.uk (2007) Help for smokers who want to quit. (Accessed; 17 July 2017). 